TOPIC IV.C.1.

OSCAR S. GRAY

\title{
Constitutional Protection of Freedom of Expression in the United States as It Affects Defamation Law
}

American constitutional law is distinguished by its protection of defamers, rather than the defamed. ${ }^{1}$ The principal constitutional source is the First Amendment to the U.S. Constitution, ${ }^{2}$ which prohibits Congress from "mak[ing] . . . [any] law . . . abridging the freedom of speech, or of the press." Since at least $1925^{3}$ the protection of the First Amendment, whatever it may be, has been assumed to apply against the states of the Union as well, as an aspect of "liberty" protected under the Fourteenth Amendment ${ }^{4}$ to the Constitution. Yet it is only for a quarter century, since 1964, that this

OsCar Gray is Professor of Law, School of Law, University of Maryland.

1. Compare the Basic Law of the Federal Republic of Germany. While Art. 5 para. (1) provides for freedom of the press, of reporting, and "the right freely to express and disseminate ... . opinion," other "Basic Rights" include "inviolability of personal honour" (Art. 5, para. (2)), dignity (Art. 1, para. (1)), and "the free development of ... personality" (Art. 2, para. (1)). The German courts have recognized a private cause of action in damages for the invasion of the constitutional right of personality. Cf. Quint, Free Speech and Private Law in German Constitutional Theory, 48 Md. L. Rev. 247 (1989).

2. Freedom of expression can also be protected by state constitutions. A state may grant more protection under its own constitution than is required by the federal constitution. For instance, analogously, the right to use a public highway for orderly communication is protected under the federal constitution, but this right has not been extended by the Supreme Court to roadways and parking areas in privatelyowned shopping plazas. Lloyd Corp. v. Tanner, 407 U.S. 551 (1972); Hudgens v. NLRB, 424 U.S. 507 (1976). Yet such a right is recognized under the California constitution. Robins v. Pruneyard Shopping Center, 23 Cal.3d 899, 153 Cal. Rptr. 854, 592 P.2d 341 (1979), aff'd sub nom. PruneYard Shopping Center v. Robins, 447 U.S. 74 (1980). Cf. similarly State v. Schmid, 84 N.J. 535, 423 A.2d 615 (1980); Commonwealth v. Tate, $495 \mathrm{~Pa}$. 158, 432 A.2d 1382 (1981). Cf. Spiritual Psychic Science Church of Truth, Inc. v. City of Azusa, 39 Cal.3d 501, 519, 217 Cal. Rptr. 225, 235, 703 P.2d 1119, 1129 (1985) (California constitutional provision on freedom of speech described as "more definitive and inclusive than the First Amendment"; provision held to apply broadly to fortune telling); compare Brown v. Kelly Broadcasting Co., 48 Cal.3d 711, 745-746, 257 Cal. Rptr. 708, 729-730, 771 P.2d 406, 427-428 (1989) (denying general "public interest" privilege for defamation of private persons; rejecting contention that California constitution provides greater protection for freedom of speech, in terms of standard of liability, than does federal constitution, and noting that state constitution imposes responsibility for abuse of the right to free speech).

3. Cf. Gitlow v. People of State of New York, 268 U.S. 652, 666 (1925).

4. "... [N]or shall any State deprive any person of life, liberty, or property without due process of law. ..." U.S. Const., Amend. XIV, Sec. 1. 
constitutional protection has been deemed to invalidate basic elements of the common law of defamation.

At common law libel and slander have been strict liability torts. The publisher has been subject to liability for statements that tend to injure reputation, unless the publisher could prove the truth of the statement, or could establish that it was made on a privileged occasion. ${ }^{5}$ If an injurious statement was deemed to be false, ${ }^{6}$ it mattered not why it was false. The liability was the same in principle at least for purposes of compensatory damages ${ }^{7}$ - if the publisher lied deliberately, or erred negligently, or innocently. Damages, furthermore, could be presumed by the jury, and could, again in principle, be heavy without specific proof of actual harm. ${ }^{8}$ This was not entirely satisfactory theoretically, in terms of the potential liability of the press for innocent errors, and there was some concern that the threat of liability might tend to deter vigorous reporting of political wrongdoing. ${ }^{9}$ On the whole, however, the traditional law of defamation seemed to strike a reasonably sound balance between the interests of publishers and of their victims, until the civil rights movement of the late 1950s and the 1960s. "A 1947 study financed by Henry Luce of Time, Inc. 'found prominent newspaper lawyers and executives basically satisfied with American defamation law'.. . That same year, the American Civil Liberties Union concluded that there were no pressing problems with libel law."10

Grave problems developed, however, in the American South in the course of the civil rights movement. More particularly, the problems arose from the reaction of Southern racialist politicians to the national attention that was increasingly paid to their region's institutionalized racial discrimination. National journalism publicized the racial repression that persisted to some extent in all parts of the country, but most intractably and violently in the South. The effect

5. See generally 2 F. Harper, F. James and O. Gray, The Law of Torts $§ 5.0$ (2d ed. 1986).

6. At common law the falsity of statements alleged to be false was presumed, unless proved true by the defendant. See generally 2 F. Harper, F. James and O. Gray, supra note 5 , at $\S 5.20$.

7. Punitive damages are also available in defamation in most common law jurisdictions. See, e.g., J. Jackson, Malice in Wonderland: Robert Maxwell v. Private Eye 172 (1986) (award of $£ 50,000$ exemplary damages). The fault of defendant is, of course, always relevant to punitive damages. In some jurisdictions, however, punitive damages are not available in defamation actions, e.g., Stone v. Essex County Newspapers, Inc., 367 Mass. 849, 860-861, 330 N.E.2d 161, 169 (1975); Wheeler v. Green, 286 Or. 99, 119, 593 P.2d 777, 789 (1979); Taskett v. King Broadcasting Co., 86 Wash.2d 439, 447, 546 P.2d 81, 86 (1976).

8. See note 5 , supra. (1966)

9. See, e.g., R. Phelps and E. Hamilton, Libel: Rights, Risks, Responsibilities 5

10. Brown v. Kelly Broadcasting Co., 48 Cal.3d 711, 750, 257 Cal. Rptr. 708, 732733, 771 P.2d 406, 430-431 (1989). 
on public opinion became politically significant. In retaliation, lawyers in Montgomery, Alabama devised a potentially lethal weapon against the national press.

On March 29, 1960, The New York Times had published an advertisement sponsored by a committee headed by a distinguished Negro leader, A. Philip Randolph, purportedly including 64 named signatories, ${ }^{11}$ calling for support of the civil rights struggle. Of about 650,000 copies of the Times published that day, about 35 circulated in Montgomery County, Alabama. There, in the City of Montgomery, the local government was managed by three elected Commissioners, including L. B. Sullivan. Neither Sullivan nor any of his colleagues was named, or referred to, in the advertisement. That advertisement did, however, describe police abuses against student demonstrators, and in certain trivial respects contained errors. ${ }^{12}$ Sullivan sued the Times, claiming that his duties included supervision of the Montgomery Police Department - as well as the Fire Department and the Departments of Cemetery and of Scales. As such, he contended, allegations of police misconduct would be understood to reflect adversely on him, if they were believed. He accordingly sued for $\$ 500,000$. The jury awarded him the entire amount he requested although nobody testified that any imputations unfavorable to Sullivan's reputation were actually believed. The judgment was affirmed by the Alabama Supreme Court on the basis of a number of elements of traditional libel doctrine, including the jury's right to award presumed damages in the absence of any evidence of actual damage. In the meantime suits by other plaintiffs against the Times, based on the same advertisement, in which they also were not named, claimed an additional $\$ 2.5$ million in damages. ${ }^{13}$

It was obvious that the United States faced a constitutional crisis, if the Sullivan award were not reversed. The national press could have been forced, under threat of bankruptcy, to withhold circulation from the South for fear of pretextual libel awards by bigoted local juries, upheld by state judges under traditional defamation doctrine. Some basis for federal interference had to be found. The Supreme Court adopted a rather sweeping basis for intervention. It predicated a constitutional role for the judiciary on two concepts: first, the inclusion of freedom of speech as among the

11. Some, including three individual co-defendants in the litigation, denied that they had authorized the use of their names.

12. For instance, nine students had been expelled from school for demanding service at a lunch counter rather than for having led a demonstration; Dr. Martin Luther King had been arrested only four times, rather than seven, as the advertisement stated. New York Times Co. v. Sullivan, 376 U.S. 254, 258-259 (1964).

13. See Lewis, "Annals of Law: The Sullivan Case," The New Yorker, November 5, 1984, at 52; Lewis, "New York Times v. Sullivan Reconsidered: Time to Return to "The Central Meaning of the First Amendment," 83 Colum. L. Rev. 603 (1983). 
"liberty" interests protected from State action by the Fourteenth Amendment; and, second, the notion that the enforcement by state courts of a state rule of libel law that penalizes the exercise of constitutionally protected speech constitutes "State action" that is subject to Fourteenth Amendment limitation, notwithstanding that the rule of libel law in question is invoked only in litigation between private parties. ${ }^{14}$

Substantively, the Supreme Court in Sullivan adopted "a federal rule that prohibits a public official from recovering damages for a defamatory falsehood relating to his official conduct unless he proves that the statement was made with 'actual malice' - that is, with knowledge that it was false or with reckless disregard of whether it was false or not."15

Such "actual malice," moreover, must be proved with "convincing clarity."16 On review appellate judges must, indeed, make an independent examination of the record to determine whether the evidence is of sufficiently convincing clarity, ${ }^{17}$ as must trial judges at the summary judgment stage. ${ }^{18}$

As to the meaning of "public official" for purposes of the Sullivan doctrine, the courts have not been entirely clear. Not all public employees were intended to be covered. The Supreme Court has said that the "employee's position must be one which would invite public scrutiny and discussion of the person holding it, entirely apart from the scrutiny and discussion occasioned by the particular charges in controversy"19 and that the designation "applies at the very least to those among the hierarchy of government employees who have, or appear to the public to have, substantial responsibility or control over the conduct of governmental affairs."20 Lower courts have been divided, for instance, as to whether low-ranking police officers should be deprived of the traditional protection of defamation law as "public officials." 21 Relatively minor functionaries have been accorded the disabling accolade by some courts, e.g.,

14. New York Times Co. v. Sullivan, 376 U.S. 254 (1964).

15. Id., 376 U.S. at $279-280$.

16. Id., 376 U.S. at 285-286.

17. Bose Corp. v. Consumers Union of United States, Inc., 466 U.S. 485 (1984).

18. Anderson v. Liberty Lobby, Inc., 477 U.S. 242 (1986).

19. Rosenblatt v. Baer, 383 U.S. 75, 86 (1966).

20. Id., 383 U.S. at 85.

21. Compare Coughlin v. Westinghouse Broadcasting and Cable, Inc., 603 F. Supp. 377, 385 (E.D. Pa. 1985) (police officers are consistently treated as "public officials") with Redmond v. Sun Publ. Co., 239 Kan. 30, 33-34, 716 P.2d 168, 171 (1986) (contra). Cf. Jones v. Palmer Communications, Inc., 440 N.W.2d 884, 895 (Iowa 1989) ("It strains credibility to say that Jones, as a low-ranking fire fighter, had substantial responsibility for the conduct of governmental affairs."). 
the clerk of a county district court, ${ }^{22}$ a grand juror, ${ }^{23}$ the supervisor of a branch post office, ${ }^{24}$ an assistant public defender. ${ }^{25}$

There has been somewhat more guidance, albeit incomplete, on the meaning of "reckless disregard," the alternative under the Sullivan rule to actual knowledge of the falsity of the statement. The mere failure to verify a report does not automatically suffice. The Supreme Court has required "sufficient evidence to permit the conclusion that the defendant in fact entertained serious doubt as to the truth of his publication." 26 That Court has also, however, said that the "finder of fact must determine whether the publication was made in good faith. Professions of good faith will be unlikely to prove persuasive, for example, where a story is fabricated by the defendant, is a product of his imagination, or is based wholly on an unverified anonymous telephone call. Nor will they be likely to prevail when the publisher's allegations are so inherently improbable that only a reckless man would have put them in circulation. Likewise, recklessness may be found where there are obvious reasons to doubt the veracity of the informant or the accuracy of his reports."27

Finally, it appears - as will be discussed below ${ }^{28}$ - that the public official will have to prove not only "actual malice," but the falsity of the statement at issue, a proposition that is a necessary corollary of proof of actual knowledge of falsity, but not necessarily of "reckless disregard" of whether a statement is true.

These limitations to the protection of defamed public officials have been extended to candidates for public office, ${ }^{29}$ and to "public figures" 30 as well. "Public figure" has been defined to include both "an individual [who] may achieve such pervasive fame or notoriety that he becomes a public figure in all contexts" and "an individual [who] voluntarily injects himself or is drawn into a particular public controversy and thereby becomes a public figure for a limited range of issues." The Supreme Court has cautioned that it "would not lightly assume that a citizen's participation in community and professional affairs rendered him a public figure for all purposes . . . It is preferable to reduce the public figure question to a more meaning(1968)

22. Theckston v. Triangle Publications, Inc., 100 N.J. Super. 452, 242 A.2d 629

23. Standke v. B. E. Darby \& Sons, Inc., 291 Minn. 468, 193 N.W.2d 139 (1971).

24. Silbowitz v. Lepper, 32 A.D.2d 520, 299 N.Y.S.2d 564 (1969).

25. Tague v. Citizens for Law \& Order, Inc., 75 Cal. App.3d 16, 142 Cal. Rptr. 689 (1977).

26. St. Amant v. Thompson, 390 U.S. 727, 731 (1968).

27. Id., 390 U.S. at 732.

28. See text at notes 49 et seq. infra.

29. Monitor Patriot Co. v. Roy, 401 U.S. 265 (1971).

30. Curtis Publ. Co. v. Butts, 388 U.S. 130 (1967). 
ful context by looking to the nature and extent of an individual's participation in the particular context giving rise to the defamation."31

Later, the Supreme Court has gone even further in modifying the common law of defamation, by attaching constitutional protection to the defamation of private persons as well as public officials and public figures. Here a different test has been applied from that in Sullivan. At least in certain contexts, to be discussed below, the Supreme Court has required that the defamation of non-public figures be non-actionable as a strict liability tort. "Actual malice" is not necessarily required, although states are free to require it for private as well as public plaintiffs. ${ }^{32}$. Instead, under the Supreme Court's decision in Gertz v. Robert Welch, Inc., ${ }^{33}$ states may define for themselves the standard of liability "so long as they do not impose liability without fault." 34 Most states have adopted negligence as the applicable standard. ${ }^{35}$ In Gertz this limitation purports to apply to the standard "for a publisher or broadcaster of defamatory falsehoods."36 The question of whether the same requirement applies to other defamers, e.g., private individuals, has not been definitively resolved, but the evidence is strong, based on the Supreme Court's treatment of an apparently analogous question, that the same standard will apply to "media" and "non-media" defendants alike. ${ }^{37}$

Another distinction, however, scarcely foreshadowed in Gertz, has come to the fore. It has arisen in connection with one of three additional requirements - apart from that on the standard of care - that were announced in Gertz. This had to do with damages.

At common law two rules, both invoked at the trial of the Sullivan case, provided broad latitude for the imposition of damages in defamation actions.

Under one, the normal rule of punitive damages, such awards could be made based on state requirements for "malice" in one sense or another, e.g., spite, ill-will, reckless disregard of the interests of others, or the like. ${ }^{38}$ Under the other, noted above, juries could

31. Gertz v. Robert Welch, Inc., 418 U.S. 323, 351-352 (1974).

32. Cf., e.g., Diversified Management, Inc. v. Denver Post, Inc., 653 P.2d 1103 (Colo. 1982) (applicable where "matter involved is of public or general concern"); Aafco Heating \& Air Conditioning Co. v. Northwest Publications, Inc., 162 Ind. App. 671, 321 N.E.2d 580 (1975), cert. denied, 424 U.S. 913 (1976).

33. 418 U.S. 323 (1974).

34. Id., 418 U.S. at 347.

35. See 2 F. Harper, F. James and O. Gray, supra note $5, \S 5.0$ n.29.

36. See note 34, supra.

37. See text at notes 41 et seq., infra.

38. Cf. 4 F. Harper, F. James and O. Gray, note 5 supra, at $\S 25.5$ A notes $15-18$. 
award "presumed" compensatory damages without proof of the existence or magnitude of actual harm.

In Gertz the Supreme Court stated that neither punitive nor presumed damages could be awarded to private plaintiffs unless they proved the "actual malice" that was required in Sullivan for public officials. ${ }^{39}$ Since the common law "malice" traditionally required for punitive damages did not necessarily include the knowledge of falsity or "reckless disregard" of truth that comprise the constitutional "actual malice" test - a spiteful hater could be a sincere believer this rule seemed to represent a severe curtailment in the availability of punitive damages for non-public victims in defamation. And, in the absence of "actual malice," presumed damages could no longer be awarded. Compensation would instead be limited to "actual injury." But "actual injury is not limited to out-of-pocket loss. Indeed, the more customary types of actual harm inflicted by defamatory falsehood include impairment of reputation and standing in the community, personal humiliation, and mental anguish and suffering." 40

The Gertz limitation on punitive damages was tested in the following decade in a case that arose in Vermont against a commercial credit reporting service: That service, Dun and Bradstreet, had falsely attributed bankruptcy to plaintiff; the service had also resisted cooperation in disseminating an effective correction when it had been informed of the error. That the defendant had been at least unreasonable was manifest. Its culpability was even greater, sufficient to satisfy Vermont's common law test for punitive damages ("insulting, reckless, and in total disregard of plaintiff's rights"). The common law test, rather than the elements of the Sullivan "actual malice" test, had been the basis for the instruction to the jury on punitive damages, and was upheld by the Vermont Supreme Court, on the theory that Gertz does not apply to non-media defendants. The jury had also been permitted to find "presumed" damages, without a finding of "actual malice," on the same theory. The United States Supreme Court upheld the result in Dun \& Bradstreet, Inc. $v$. Greenmoss Builders, Inc. ${ }^{41}$ but on a different rationale: not that there is a difference between the law applicable to "media" and "nonmedia" defendants, but, apparently, 42 that Gertz - at least as it deals with presumed and punitive damages - applies only to "speech involving ... matters of public concern." 43

Unresolved, at the level of the Supreme Court, is the question

39. 418 U.S. at 349 .

40. 418 U.S. at 350. Cf. Time, Inc. v. Firestone, 424 U.S. 448 (1976).

41. 472 U.S. 749 (1985).

42. The reasoning is expressed in a plurality opinion.

43. 472 U.S. at 757-761. 
whether the same notion applies to the Gertz requirement that private plaintiffs must show fault in order to collect compensation damages in defamation. Parity of reasoning would suggest that traditional strict liability in defamation has survived Gertz, constitutionally, in actions by private plaintiffs, even against "media" defendants, for defamation that does not involve "matters of public concern." 44 But the force of reasoning is an uncertain determinant of future Supreme Court action. Predictability is particularly uncertain because the reasoning depends on ideas espoused by a mere plurality of the Court. It also requires assimilation of an additional element - the relationship between the concept of "matters of public concern" and the implications of "media" publication, in terms of the publisher's assumptions about the interest of the public in the material presented.

Another statement in Gertz, amounting only to dicta in that opinion, has had a large effect on the protection accorded freedom of expression in terms of constitutional limitations on liability for defamation. "Under the First Amendment there is no such thing as a false idea. However pernicious an opinion may seem, we depend for its correction not on the conscience of judges and juries but on the competition of other ideas." 45 The tendency of lower courts since Gertz has been overwhelmingly to rely on this proposition to restrict the scope of the defamation action. ${ }^{46}$ This tendency has been marked in several different contexts. The proposition has helped clarify and replace one of the more puzzling features of traditional doctrine, the privilege of "fair comment." This privilege long served a useful function in preserving freedom to discuss with enthusiasm political, literary, and artistic questions and similar matters of customary criticism. The difficulty with the privilege was that it was predicated on a correct exposition of the facts underlying the criticism. Therefore the "privilege" applied only to comment. But to talk about "fair" comment is to imply the possibility of "unfair" comment. Since Gertz, it has been easier for courts to be forthright that any comment - as distinguished from false statements of fact - is non-actionable.47 Courts have also gone to great lengths to classify statements that might have been considered factual in an earlier day as expressions only of opinion. Vituperation, however immoderate, tends to be excluded systematically from the threat of liability, on the same basis. The tendency of some courts to treat statements as legally incapable of bearing a defamatory meaning, on the ground that they are regarded as expressions of opinion as a

44. Cf. text at notes 5-7 supra.

45. 418 U.S. 323, 339-340 (1974).

46. See generally 2 F. Harper, F. James and O. Gray, supra note 5 , at $\S 5.8$.

47. Id. at notes $6-13$. 
matter of law, has been marked. ${ }^{48}$

Finally, an important reversal has occurred, again on constitutional grounds, in the burden of proof as to truth or falsity. At common law the defendant has the burden to establish truth (or "justification").49 This was considered fair on the ground that defamatory falsehoods are often difficult to disprove, perhaps because refutation requires "proof of a negative," or because it is difficult to plead with specificity the denial of accusations made in general terms. ${ }^{50}$ By contrast it seemed not unfair to call on the person who has made an accusation in general terms to come forward with particulars that would substantiate it. Questions arose after the Sullivan case, however, as to whether the constitutional requirements for proof of "actual malice" necessarily implied a requirement that plaintiff establish falsity. Plaintiffs who seek to prove defendant's knowledge of falsity will, of course, have to prove falsity in the process, but, as noted above, one's indifference to the question whether a statement is true or false can be established without proof of the truth or falsity of the statement. Similarly, for purposes of Gertz, proof of the negligence of a publisher does not turn on the truth or falsity of the matter published. Nevertheless, in Philadelphia Nevospapers, Inc. $v$. Hepps, ${ }^{51}$ the Supreme Court reversed, on grounds of burden of proof, a judgment for a plaintiff whose company had been reported to have "had connections . . . with organized crime." If "the speech at issue is of public concern," the Supreme Court ruled that "a private-figure plaintiff must bear the burden of showing that the speech at issue is false before recovering damages from a media defendant."52 The Court was closely divided (five-to-four). Two of

48. Cf. Edwards v. National Audubon Soc., 556 F.2d 113 (2d Cir. 1977) (nonactionable to call a scientist a "liar" in his use of statistics, but calling him a "paid liar" might be actionable); Rinaldi v. Holt, Rinehart \& Winston, Inc., 42 N.Y.2d 369, 382, 397 N.Y.S.2d 943, 951, 366 N.E.2d 1299, 1307, cert. denied, 434 U.S. 969 (1977) (statement that judge is "incompetent" and should be removed is one of opinion; that he is "probably corrupt" is imputation of fact). There has been a similar tendency by some American courts to treat as nondefamatory, as a matter of law, statements that those courts interpret to be non-harmful to reputation, although others might well have regarded them as ambiguous, at best, and therefore for the jury to construe. See, e.g., Fleming v. AT\&T Information Services, Inc., 878 F.2d 1472 (D.C. Cir. 1989); Masson v. The New Yorker Magazine, Inc., 881 F.2d 1452, 1456-1458 (9th Cir. 1989); compare Hartt v. Newspaper Publishing Plc, The Times (London), Nov. 9, 1989, at 39, col.1 (C.A.) ("The hypothetical reasonable reader ... . could read between the lines. He could read in an implication more readily than a lawyer . . ..").

49. See generally 2 F. Harper, F. James and O. Gray, supra note 5, at $\S 5.20$.

50. Cf. Murnaghan, "Ave Defamation, Atque Vale Libel and Slander," 6 U. Balt. L. Rev. 27, 40 (1976); Rinaldi v. Holt, Rinehart \& Winston, Inc., 42 N.Y.2d 369, 397 N.Y.S.2d 943, 366 N.E.2d 1299 (1977).

51. 475 U.S. 767 (1986).

52. 475 U.S. at 787. The Court specifically declined to rule on whether the common law rule could apply to a declaratory judgment action that did not involve liability for damages. 475 U.S. at 779, n.4. 
the justices in the majority stated, in a concurring opinion, that there should be no constitutional distinction between media and nonmedia defendants. ${ }^{53}$ Whether such a distinction would be applied remains uncertain, as does the issue of defining speech "of public concern." As the dissenting opinion points out, the decision licenses publishers who, it can be proved with convincing clarity, act in bad faith - with an indifference to truth amounting to "actual malice" - to fabricate accusations "for no other purpose than to destroy the reputation of the plaintiff," so long as the publisher knows "that it would be impossible for a court to verify or discredit the story." 54 Accordingly one may regretfully conclude with the dissenters that "[ $t]$ he Court's decision trades on the good names of private individuals with little First Amendment coin to show for it." 55

53. 475 U.S. at 779-780.

54. 475 U.S. at $780-790$ (per Stevens, J.).

55. Ibid. 